ALINA FILINOWICZ

Uniwersytet w Białymstoku

\title{
Michał Kondratiuk, Nazwy geograficzne i osobowe Bialostocczyzny. Funda- cja Księcia Konstantego Ostrogskiego w Białymstoku, Orthdruk, Białystok 2016, ss. 800
}

Nazwy geograficzne i osobowe Białostocczyzny - to kolejna książka wybitnego językoznawcy, dialektologa, onomasty pogranicza polsko-wschodniosłowiańskiego i słowiańsko -bałtyckiego - prof. zw. dra hab. Michała Kondratiuka.

Obszerna, licząca 800 stron, publikacja zawiera, wybór prac onomastycznych opublikowanych w różnych czasopismach krajowych i zagranicznych, i dlatego dziś trudno dostępnych. W tomie znalazły się prace naukowe i popularnonaukowe, artykuły, opracowania, przyczynki, studia z zakresu toponimii, mikrotoponimii oraz nazw osobowych pogranicza polsko-wschodniosłowiańskiego.

Główną część publikacji poprzedza przedmowa, życiorys naukowy i pełna bibliografia prac naukowych Autora za lata 1962-2016 (s. 17-38). W dalszej części umieszczono nazwiska wypromowanych doktorów oraz zestawienie prac magisterskich i licencjackich wykonanych pod kierunkiem prof. M. Kondratiuka, ze wskazaniem roku i tytułu prac absolwentów.

Wybrane prace językoznawcze zamieszczone w książce ułożono w trzech rozdziałach. Pierwszy - Artykuly i prace mieszane (s. 49-194) zawiera informacje o historii badanego terenu, jego osadnictwie, dziejach politycznych; stanie i problematyce badań onomastycznych (Badania onomastyczne w regionie biatostockim. Stan i perspektywy, s. 49-72); specyfice badań na pograniczu językowym, etnicznym i konfesyjnym ( $O$ metodologii badań onomastycznych na pograniczu polsko-wschodniostowiańskim $i$ stowiańsko-baltyckim, s. 96-106). Znalazły się tu artykuły poświęcone etymologii nazw geograficznych i osobowych, problemom kontaktów międzyjęzykowych polsko-wschodniosłowiańsko-bałtyckiego pogranicza. Jest też artykuł o roli języka i nazw własnych w samoidentyfikacji mniejszości narodowych i etnicznych.

Rozdział II - Nazwy osobowe (s. 197-399) obejmuje antroponimię Białostocczyzny. Uwzględniono tu nazwiska używane współcześnie i występujące w źródłach historycznych, np. w lustracjach dóbr królewskich, prywatnych i duchownych, inwentarzach starostw i leśnictw, w taryfach podymnego i pogłównego oraz w popisach wojsk litewskich. Autor pracy ujawnił szeroki udział wschodniosłowiańskich, głównie białoruskich elemen- 
tów językowych w antroponimii badanego terenu (Tendencje słowotwórcze w nazwach mieszkańców na pograniczu polsko-białorusko-ukraińskim, s. 197-212; Odapelatywne nazwiska wschodniostowiańskie mieszkańców Białostocczyzny, s. 381-391). Innym interesującym zagadnieniem, któremu prof. M. Kondratiuk poświęcił dużo uwagi, są nazwy osobowe litewskiego pochodzenia notowane na obszarze północno-wschodniej Polski. W obszernym artykule - Nazwiska pochodzenia bałtyckiego $w$ regionie biatostockim (s. 277-317), poddano analizie językowej ponad 220 nazwisk (od litery A do J), wskazano elementy litewskie obecne we współcześnie używanych nazwiskach mieszkańców regionu białostockiego, podano ich lokalizację i etymologię. W tej części umieszczono też ciekawe artykuły o rzadkich oraz powszechnych nazwiskach litewskiego pochodzenia występujących w Polsce (objaśniono m.in. nazwiska Karejwo, Kimsza, Kujta; Karwel, Kieda, Kiszkiel i wiele innych, s. 318-344).

Rozdział III - Nazwy geograficzne (s. 403-777) poświęcono nazwom miejscowym i terenowym badanego obszaru, ich powstaniu, historii, zmianom oraz etymologii. Na uwagę zasługują prace wskazujące na obecność bałtyckich nazw geograficznych w regionie białostockim. Umieszczono tu m.in. artykuł o metodach slawizacji bałtyckich nazw geograficznych na pograniczu polsko-białorusko-litewskim (s. 666-678), a także ważną pracę o bałtycko-słowiańskich hybrydach nazewniczych w ojkonimach i mikrotoponimach Białostocczyzny (s. 610-621), jak również nazwach komponowanych słowiańsko-bałtyckich w toponimii północno-wschodniej Polski (s. 691-698). Ujawnienie wpływów bałtyckich na nazwy geograficzne słowiańskie stało się podstawą do sformułowania wniosków o dawnych stosunkach etniczno-językowych na Podlasiu.

Kilka opracowań z rozdziału III ma charakter popularnonaukowy. Jest to cykl artykułów pod wspólnym tytułem Skąd wzięła się ta nazwa? oraz Tajemnice nazw własnych; ich celem jest zapoznanie mieszkańców Białostocczyzny, zwłaszcza młodzieży i studentów z toponimią Białostocczyzny, z jej historią i dziejami języka.

Ważnym uzupełnieniem publikacji jest umieszczony na końcu Indeks nazw geograficznych $i$ osobowych, który zawiera wykaz nazwisk i miejscowości objaśnionych w książce.

Publikacja liczy 66 artykułów, większość z nich napisano w języku polskim, ale są też teksty w języku białoruskim i rosyjskim. Do niektórych prac dołączono mapy historyczne, osadnicze, fonetyczne, administracyjne i inne badanego terenu. Artykuły opatrzono bogata literaturą z zakresu antroponimii i toponimii polskiej, wschodniosłowiańskiej, bałtyckiej, historii osadnictwa i dialektologii. Zarówno prace poświęcone nazwom osobowym jak i geograficznym obok nazw oficjalnych mają formy gwarowe zapisane w transkrypcji. Uwzględnienie postaci gwarowych nazw jest niezbędne w badaniach pograniczy językowych i obszarów językowo mieszanych.

Wieloletnie doświadczenie badawcze profesora Michała Kondratiuka, kompetencje, rozległa wiedza teoretyczna i praktyczna, wpłynęły na to, że prace prezentowane w książce są oryginalne, rzetelne, oparte na bogatych źródłach historycznych - drukowanych i rękopiśmiennych, znajdujących się w archiwach krajowych i zagranicznych oraz dobrej znajomości osadnictwa i gwar badanego obszaru. Warto nadmienić, iż prof. M. Kondratiuk od roku 1958 roku wchodził w skład zespołu eksploratorów zbierających materiały gwarowe do Atlasu gwar wschodniostowiańskich Białostocczyzny (zapisał gwary z ponad pięćdziesięciu wsi, co stanowi około 40\% całej kartoteki gwarowej). Natomiast w latach 1961-1969 z zespołem filologów, pod kierunkiem prof. Antoniny Obrębskiej-Jabłońskiej, prowadził 
w województwie białostockim rejestrację nazw miejscowości i obiektów fizjograficznych na zlecenie Komisji Ustalania Nazw Miejscowości przy Urzędzie Rady Ministrów Rzeczypospolitej Polskiej. Zebrał materiały onomastyczne z sześciu istniejących wówczas powiatów (z życiorysu Autora na s. 12-15).

Bez wątpienia prezentowana książka w znaczący sposób wzbogaca naszą wiedzę o specyfice nazewnictwa geograficznego i osobowego Białostocczyzny. Stanowi jakoby świadectwo istnienia zróżnicowanego etnicznie, językowo i konfesyjnie osadnictwa Polski północno-wschodniej. Zainteresuje z pewnością badaczy języka, onomastów, studentów, mieszkańców województwa podlaskiego oraz czytelników chcących poszerzyć wiedzę w zakresie nomenklatury nazewniczej.

Praca i zamieszczone w niej artykuły o charakterze popularnonaukowym służą upowszechnieniu nauki i cieszą się dużym zainteresowaniem czytelników.

Nie bez znaczenia jest i to, że książka charakteryzuje się estetyką wydania: twarda stylowa oprawa, dobrej jakości papier, czytelna czcionka, przemyślany podział materiału, czynią publikację nie tylko pożyteczną, ale i przyjemną. 